\title{
Ergenlerde Şükran, Yaşam Amaçları ve Yaşam Doyumunun Bazı Değişkenler Açısından İncelenmesi
}

\section{Özcan SEZER ${ }^{* *}$, Engin TURĞUT ${ }^{* *}$}

Öz: Bu araştırmanın amacı, ortaöğretim düzeyindeki ergenlerde şükran, yaşam doyumu ve yaşam amaçları arasındaki ilişkiyi incelemektir. Bu nedenle araştırmada tarama modeli kullanılmıştır. Çalışmanın örneklem grubu Van ilinin merkez ilçelerinde yer alan Fen Liseleri, Anadolu Liseleri, Anadolu İmam Hatip Liseleri ile Mesleki ve Teknik Anadolu Liselerinde okuyan 603 öğrenciden oluşmaktadır. Verileri toplamada Şükran Ölçeği, Yaşam Amaçları Ölçeği, Yaşam Doyumu Ölçeği ve Kişisel Bilgi Formu kullanılmıştır. Elde edilen veriler üzerinde Frekans (f), Yüzde (\%), t-test, varyans analizi (ANOVA) ve regresyon analizleri yapılmıştır. Araştırma sonucunda cinsiyetin yaşam doyumu ve yaşam amaçlarını etkileyen bir değişken olmadığı ancak cinsiyetin ergenlerin şükran düzeyini etkileyen bir faktör olduğu belirlenmiştir. Katılımc1 ergenlerde şükran düzeyi ile yaşam doyumu ve yaşam amaçları arasında pozitif bir ilişkinin olduğu bulgusuna ulaşılmıştır. Ayrıca şükran düzeyinin Fen Lisesi ve Anadolu Liselerinde öğrenim gören öğrencilerde daha yüksek olduğu görülmüştür. Buna karşın yaşam doyumu açısından Fen Lisesi ve Anadolu İmam Hatip Liselerinde öğrenim gören öğrencilerin daha yüksek doyuma sahip oldukları belirlenmiştir. Yaşam amaçları açısından sadece Fen Lisesi öğrencileri ile Anadolu İmam Hatip Liselerine giden öğrenciler arasında anlamlı bir farka rastlanmıştır. Ailelerinin gelir durumuna göre şükran, yaşam doyumu ve yaşam amaçları alanlarında anlamlı fark olduğu bulgusuna da ulaşılmıştır. Şükran ve yaşam amacının birlikte yaşam doyumunu \% 21 düzeyinde açıkladığı, şükranın tek başına yaşam doyumunun \% 19'unu yordadığı bulgusuna da ulaşılmıştır. Elde edilen bulgular ışığında bazı önerilerde bulunulmuştur.

Anahtar Kelimeler: Şükran, Yaşam amacı, Yaşam doyumu, Ergenler

\footnotetext{
* İnönü Üniversitesi Eğitim Fakültesi, Eğitim Bilimleri Bölümü, Türkiye. ORCID ID:0000-0002-0846-4892, Eposta: ozcan.sezer@inonu.edu.tr

** Yüzüncü Yıl Üniversitesi Eğitim Fakültesi, Eğitim Bilimleri Bölümü, Türkiye. ORCID ID:0000-0002-1990-4988, E-posta: enginturgut@yyu.edu.tr
} 


\section{An Investigation of Gratitude, Life Goals, Life Satisfaction of Adolescents In Terms Of Some Variables}

Abstract: The purpose of this study is to investigate the relationship between life satisfaction, gratitude and life goals in adolescents at high school level. Therefore, the scanning model was used. The sample group consists of 603 students who study in Science High Schools, Anatolia High Schools, Anatolia Religious Vocational High Schools, and Vocational and Technical Anatolian High Schools in the central districts of Van province. The questionnaires and scales were used to collect data. The data were subjected to frequency (f) and percent (\%) analysis, t-test, variance analysis (ANOVA), and regression analysis. As a result of the study, it was determined that the gender of the participants was not a variable affecting life satisfaction and life goals but a factor affecting the level of gratitude. It was found that there was a positive relationship between gratitude levels and life satisfaction and life goals. In addition, it was found that the level of gratitude was higher in students who were educated in Science and Anatolian high schools. On the other hand, it was determined that the students who were educated in Science High Schools and Anatolia Religious Vocational High Schools had higher saturation at the point of life satisfaction. It was found a significant difference in terms of the point of life goals between the students who went to Anatolia Religious Vocational High Schools and the students who went to Science High Schools. According to the income status of their families, it was determined that gratitude, life satisfaction, and life goals were significantly different. It was also found that gratitude and life goals are together explained life satisfaction at the $21 \%$ level. It has also been found that gratitude alone makes $19 \%$ of the satisfaction of life. Some suggestions were made to pay attention to these studies in this area.

Keywords: Gratitude, Life goals, Life satisfaction, Adolescents 


\section{Giriş}

Ergenlik, önemli bir gelişim süreci olması yanında birçok problemin de yaşandığı dönemdir. Erikson'a göre, kimlik veya benlik duygusunun kazanımı göz önüne alındığında, bu dönemde ortaya çıkan problemlerle sağlıklı bir şekilde yüzleşilmesi ergenler için fayda sağlayacaktır. Bilişsel, duygusal, fiziksel ve sosyal alanlarda pek çok değişimin bir arada yaşandığı bu dönem (Yörükoğlu, 2004) diğer gelişim dönemlerinden çeşitli açılardan farklılaşır (Eryılmaz, 2009). Ergenlik dönemi coşkulu, heyecanlı, çalkantılı, tutkulu, firtınalı bir dönemdir ve yaşamın tüm diğer gelişim alanlarını etkilemektedir. Bu dönemindeki gençler (ergenler) kendini arayıp bulma, kanıtlama ve yaşamlarının amaçlarını oluşturmak için çabalamaktadırlar (Tarhan, 2019). Çeşitli etkinliklerle kendi yaşamlarının anlamı olarak gördükleri şeyleri ortaya koymaya çalışırlar. Anlamlı şeyler yaparak kişisel ve sosyal açılardan kendilerini iyi hissetmek isterler. Kişilik birçok erdemden oluşur ve şükran da bu erdemlere ulaşmada güçlü kişilik özelliklerinden biridir (Carr, 2016). Şükran, sürdürülebilir mutluluğu elde etmek için gerekli olan bileşenlerden biri olarak kabul edilmektedir (Lyubomirsky, 2008). Şükran duygusu ise bireylerin kişisel ve sosyal iyi oluşlarıyla doğrudan veya dolaylı olarak ilişkili olduğu görülmektedir (Kardaş ve Yalçın, 2018).

Şükran kavramı; duyuşsal-bilişsel boyutlara sahip olup, hem duygulanımın hem de bilişlerin baskın bir bileşeni olduğu karmaşık bir yapı göstermektedir (Kardaş ve Yalçın, 2018). Yaygın olarak deneyimlenen bir duygu olarak şükran, yaşamı armağan olarak görmeye yönelik bir eğilimi ifade etmektedir (Kardaş ve Yalçın, 2018). Görülen bir faydaya karşı minnet hissi veya bunu ona sağlayana karşı minnet duymak (Emmons, 2004) olarak tanımlanabilecek olan şükran duygusu, bireyin sahip olduklarına karşı iyi duygular içinde olmasını sağlar. Şükran, yaşamın anlamının gerçekleştirilmesinde daha fazla yaşam memnuniyeti sağlamaktadır (Datu ve Mateo, 2015). Ancak bazı durumlar şükran duymayı engellemektedir. Örneğin maddi şeylere çok önem verme, insanların kusurlarının olabileceğini kabul etmeme, üstünlük kurma çabası, kıskançlık ve kin duygularının yaşamda şükran duyma ile uyumlu olmadığı ve şükranı olumsuz etkilediği belirtmektedir (Emmons, 2009).

Şükranı olumsuz etkileyen bu tür durumların en fazla görüldüğü yaşam dönemlerinden biri de ergenlik dönemi olduğu söylenebilir. Çünkü kimlik oluşturma sürecinde hayatın anlamını bulmaya çalışan ve bunu amaç haline getiren ergenler, belli 
dönemlerde yerine getirmeleri beklenen görevlerin (örneğin çalışmak veya çalışmaya dair seçimler) üstesinden gelebilmek için gerekli olan becerileri edinmeye dair daha istekli olacaklardır (Datu, 2014). Locke'e (2002) göre hedefe yönelik eylem; ihtiyaçlarımızı yerine getirdiğimiz ve çeşitli değer uygulamaları, değer takibi ve değer başarısı süreçleri aracılığıyla mutluluğa ulaştığımız araçlar olmaktadırlar. Yaşamda istenen şeylerin iç temsilleri olarak tanımlanan amaçlar (Austin ve Vancouver, 1996), içsel ve dişsal olmak üzere iki tür amaçtan oluşurlar (Kasser ve Ryan, 2001). Kasser ve Ryan'na (2001) göre içsel amaçlar; kişisel gelişim, duygusal yakınlık ve topluma hizmeti, dışsal amaçlar ise; finansal başarı, fiziksel çekicilik, ün ve popülerliği kapsar. Bireyin kendini daha iyi hissedebilmesi için hem içsel hem de dışsal amaçlar edinmesi, bireyin sağlıklı bir kişilik geliştirmesi ve yaşam doyumu hissedebilmesi için önemli bir ön koşu olarak görülebilir. Yaşam amacı bireyin daha anlamlı bir yaşam sürdürmesini sağlamakla birlikte, bireyin hayatında daha fazla tatmin duygusunu da hissetmesine olanak verir. Amaç belirleyip bunları gerçekleştirme çabasında bulunan bireylerin, amacı bulunmayanlara göre öznel açıdan daha iyi oldukları görülmektedir (Emmons, 1999). Bireyin yaşam amacını belirlemesi bireyin daha üretken olmasını ve işe yarıyor olma hissini de yaşamasını sağlayan bir faktördür. Bireylerin yüksek standartlar belirlemeleri ve bunları gerçekleştirmeleri yaşam doyumlarını pozitif yönde etkilerken, yüksek standartlar konusunda zorluk yaşamaları ve yüksek standartları sürdürememeleri yaşam doyumlarına negatif yöne bir etkide bulunmaktadır (Gilman ve Ashby, 2003).

Pozitif psikolojide önemli bir yapı olan yaşam doyumu (Gilman ve Huebner, 2003) ve mutluluk yaşamın en önemli hedefleri olarak görülmektedir (Gündoğar, Gül, Uskun, Demirci ve Keçeci, 2007). Yasam doyumu, bireyin kendisi için belirlediği kriterlere uygun biçimde tüm yaşamını pozitif değerlendirmesi olarak tanımlanmaktadır (Diener, Emmons, Larsen ve Griffin,1985). Yaşam doyumunu etkileyen faktörlerin ele alındığı bir çalışmaya göre pozitif ve negatif mizaç gibi kalıtsal ve genetik kişilik yapısına rağmen birçok çevresel, ailesel ve sosyal öğeler gençlerin yaşam doyumunu olumlu yönde etkilemektedir. Sağlıklı yaşam tarzı, fiziksel sağlık, egzersiz, sportif ve sosyal aktivitelere katılım, iyi aile ilişkileri, ebeveynlerle iyi iletişim, sosyal destek ve güvenli komşuların olması gençlerin yaşam doyumunu desteklemektedir. Buna karşın madde kötüye kullanımı, şiddet, öfke ve cinsel istismara maruz kalma gibi riskli 
davranışlar içinde bulunma ise yaşam doyumunu düşürmektedir (Proctor, Linley ve Maltby, 2009).

Kişinin kendisini iyi hissetmesine yol açacak özelliklerinin farkında olması ve bu özelliklerinin yoğunluğunun başkaları ile olan ilişkilerini olumlu yönde biçimlendireceği düşünülmektedir. Literatür incelendiğinde ergenlerde şükran durumunu yaşam doyumu ve yaşam amaçları ile birlikte inceleyen herhangi bir çalışmaya rastlanamamıştır. Şükran duyma durumu olumlu tepkilerle karşılanan iyi bir özellik olarak görülmektedir. Şükran duymanın, kişiye bir şeyleri takdir edebilme ve sahip olduklarıyla mutlu olabilme gibi pozitif özellikler katarak bireylerin yaşam doyumunun artmasına ve mutlu olmasına katkıda bulunacağı varsayılmaktadır. Ergenlerin şükran durumları ile ilgili yapılacak çalışmaların hem onların gelişimlerini olumlu yönde sürdürmelerine hem de alan yazının zenginleşmesine katkı sağlayacağı umulmaktadir.

Bu kapsamda bu çalışma ile elde edilmek istenen şükran duygusu yüksek olan insanların yaşam doyumları ve yaşam amaçları noktasında farklılık gösterip göstermediklerine dair olan durumu ortaya koymak ve bu durumun cinsiyetle ve bazı değişkenlere göre nasıl etkilendiğini belirlemektir.

\section{Yöntem}

\section{Araştırma Modeli}

$\mathrm{Bu}$ çalışmada, genel tarama modellerinden betimsel tarama ve ilişkisel tarama modeli kullanılmıştır. Betimsel tarama; geçmişte veya halen mevcut olan bir durumu (olay, kişi, nesne) kendi şartları içinde olduğu gibi tanımlamayı amaçlayan araştırma modeli olarak, ilişkisel tarama ise; iki ya da daha çok sayıdaki değişken arasındaki birlikte değişimin varlığını ve varsa derecesini belirlemeye imkan veren bir araştırma modeli olarak ifade edilmektedir (Karasar, 2005).

\section{Çalışma Grubu}

Bu araştırmanın katılımcıları, 2018-2019 eğitim ve öğretim yılı güz döneminde Van iline bağlı merkez ilçelerde Milli Eğitim Müdürlüğüne bağlı dört lise türünde ( Fen Lisesi: 2, Anadolu Lisesi: 1, Anadolu İmam Hatip Lisesi: 2 ve Mesleki ve Teknik Anadolu Lisesi: 2) öğrenim gören öğrencilerden oluşmaktadır. Araştırmada veriler bu yedi lisede eğitim gören 640 öğrenciden gönüllülük esasına dayalı olarak toplanmıştır. 
Hatalı ya da eksik dolduran 37 öğrencinin verileri çıkarılmış ve 603 öğrencinin verileri bilgisayara yüklenerek gerekli analizler yapılmıştır.

Katılımcıların cinsiyeti, öğrenim görmekte oldukları okul türü, sınıf düzeyleri, en son aldıkları karnedeki başarı düzeyleri ve ailelerinin gelir durumuna ilişkin demografik özellikleri Tablo 1'de verilmiştir.

Tablo 1. Demografik Değerler $(\mathrm{N}=603)$

\begin{tabular}{clll}
\hline & Değişkenler & n & \% \\
\hline \multirow{2}{*}{ Cinsiyet } & K1z & 327 & 54.2 \\
& Erkek & 276 & 45.8 \\
\hline \multirow{3}{*}{ Okul Türü } & Fen Lisesi & 148 & 24.5 \\
& Anadolu Lisesi & 191 & 31.7 \\
& Anadolu İmam Hatip Lisesi & 126 & 20.9 \\
& Mesleki ve Teknik Anadolu Lisesi & 138 & 22.9 \\
\hline \multirow{2}{*}{ Sınıf Düzeyi } & 9. Sinıf & 117 & 19.4 \\
& 10. Sinıf & 159 & 26.4 \\
& 11. Sinıf & 180 & 29.9 \\
& 12. Sinıf & 147 & 24.4 \\
\hline \multirow{2}{*}{ Bon Kaşarı Durumedeki } & Zayıfi olan & 114 & 18.9 \\
& Zayıfsı geçen & 87 & 14.4 \\
& Teşekkür alarak geçen & 240 & 39.8 \\
& Takdir alarak geçen & 162 & 26.9 \\
\hline \multirow{2}{*}{ Ailenin Gelir } & 0-1603 TL arasında & 269 & 44.6 \\
Durumu & 1604-2800 TL arasında & 176 & 29.2 \\
& 2801-4000 TL arasında & 94 & 15.6 \\
& 4001 TL ve üzeri & 64 & 10.6 \\
\hline
\end{tabular}

Tablo 1'de görüldüğü üzere kız öğrenci sayısının erkek öğrencilerin sayısından daha fazla (k1zlar: \% 54.2, erkekler: \% 45.8) olduğu görülmektedir. En fazla katılım Anadolu liselerinde (\% 31.7), en az katılım ise Anadolu İmam Hatip liselerinde (\% 20.9) olmuştur. Sınıf düzeylerine göre, en fazla katılım sağlayan sınıf düzeyi 11. sınıflarda (\% 29.9), en düşük katılım 9. sınıflarda (\% 19.4) gerçekleşmiştir. Teşekkür belgesi alan ergenlerin sayısı (\% 39.8) çoğunlukta iken, zayıfsız geçen ergenlerin (\% 14.4) en az sayıda olduğu görülmüştür. Ailenin gelir düzeyine göre bakıldığında en fazla öğrencinin 0-1603 TL arası (\% 44.6) gelir düzeyine sahip ailelerden olduğu, 4001 $T L$ ve yüksek (\% 10.6) gelire sahip ailelerden gelenlerin ise en küçük grubu oluşturduğu görülmektedir.

\section{Veri Toplama Araçları}

Şükran Ölçeği (ŞÖ): Kardaş ve Yalçın (2016) tarafından geliştirilmiş olup 25 maddeden ve altı alt boyuttan (Aile ve Çevrenin Katkılarını Fark Etme, Pozitif Sosyal Karşılaştırma, Mahrumiyet Yerine Bolluk Hissi, Olumlu Olana Odaklanma, Küçük 
Şeylere Şükran Duyma ve Şükranı İfade Etme) oluşmaktadır. Ölçek beşli Likert (Hiç Katılmıyorum, Katılmıyorum, Kararsızım, Katılıyorum ve Kesinlikle Katıliyorum) tarzda hazırlanmış olup ölçeğin bütünü için Cronbach Alpha katsayısı r=0.88'dir.

Yaşam Amaçları Ölçeği (YAÖ): Aydıner (2011) tarafından geliştirilmiştir. Toplamda 31 maddesi olan ölçeğin altı alt boyutu (Kişisel Gelişim, Bireysel Farkındalık, Maddi Kazanç, Sosyal Sorumluluk ve Fiziksel Görünüm) bulunmaktadır. YAÖ beşli Likert (Hiç, Biraz, Kısmen, Çok ve Çok Fazla) tipinde ve düz cümle halinde ifade edilen maddelerden oluşmaktadır. Cronbach Alpha güvenirlik katsayısı ölçeğin bütünü için $\mathrm{r}=0.85^{\prime}$ dir. $\mathrm{Bu}$ çalışma kapsamında toplanan verilerin Cronbach Alpha değeri $\mathrm{r}=0.85$ bulunmuştur.

Yaşam Doyumu Ölçeği (YDÖ): Diener, Emmons, Larsen ve Griffin (1985) tarafından geliştirilmiştir. Ölçek beş maddeden oluşan ve beşli Likert (Hiç Katılmıyorum, Çok Az Katılıyorum, Orta Düzeyde Katılıyorum, Büyük Oranda Katılıyorum ve Tamamen Katılıyorum) tarzdadır. Türkçe’ye uyarlaması Dağlı ve Baysal (2016) tarafından yapılmıştır. Ölçeğin tümü için Cronbach Alpha iç tutarlık katsayısı $\mathrm{r}=0.88$ olarak hesaplanmıştır. Bu çalışma kapsamında toplanan verilerin Cronbach Alpha değeri $\mathrm{r}=0.75$ bulunmuştur.

Kişisel Bilgi Formu (KBF): Araştırma kapsamında oluşturulan bu formda katılımcıların cinsiyetini, öğrenim görmekte oldukları okul türünü ve sınıf düzeyini, en son aldıkları karnelerindeki başarı durumlarını ve ailelerinin gelir durumunu belirlemeye yönelik ifadelere yer verilmiştir.

\section{Verilerin Toplanması}

$\mathrm{Bu}$ araştırma için ilgili kurumlardan alınan onay ve izinlerin ardından belirlenen okullara gidilmiş, uygulamaya başlamadan önce öğrencilere araştırmanın amacı, gönüllülük ilkesi ve ölçme araçlarının nasıl cevaplandırılacağı hakkında açıklamalar yapılmıştır. Uygulamalar yaklaşık bir ders saati içinde gerçekleştirilmiştir.

\section{Verilerin Analizi}

Verilerin analizinde; uygun paket programından yararlanılarak gruplar arasındaki farkın anlamlı olup olmadığını belirlemek amacıyla bağımsız gruplar için t testi; cinsiyet, okul türü, sınıf düzeyi, en son aldığı karnedeki başarı durumu ve ailelerinin gelir düzeyi değişkenleri için tek yönlü varyans analizi (ANOVA) ve Scheffe teknikleri kullanılmıştır. Şükran ve yaşam amaçları alt boyutları ile birlikte yaşam 
doyumunun yordayıp yordamadığını tespit etmek için aşamalı regresyon analizi kullanılmıştır. Araştırmada anlamlılık düzeyi .05 olarak kabul edilmiştir.

\section{Bulgular}

1. Şükran, Yaşam Amaçları ve Yaşam Doyumu ile Cinsiyet Değişkenine İlişkin Bulgular

Ergenlerde şükran, yaşam doyumu ve yaşam amaçları için cinsiyet değişkeni açısından anlamlı bir fark gösterip göstermediğini belirlemek amacıyla t-testi yapılmış ve sonuçları aşağıda Tablo 2'de verilmiştir.

Tablo 2. Ergenlerin Şükran, Yaşam Doyumu ve Yaşam Amaçları Puanlarının Cinsiyete Göre t-Testi Sonuçları ( $\mathrm{N}=603)$

\begin{tabular}{llcccccc}
\hline & Cinsiyet & $\mathbf{n}$ & $\overline{\mathbf{x}}$ & $\mathbf{S}$ & sd & T & P \\
\hline \multirow{2}{*}{ Şükran } & K1z & 327 & 88.19 & 17.73 & 601 & 3.72 & .000 \\
& Erkek & 276 & 83.30 & 16.41 & & & \\
\hline Yaşam & K1z & 327 & 111.30 & 15.07 & 601 & .28 & .778 \\
Amaçları & Erkek & 276 & 111.69 & 18.34 & & & \\
\hline Yaşam & K1z & 327 & 12.91 & 4.10 & 601 & .69 & .489 \\
Doyumu & Erkek & 276 & 12.67 & 4.43 & & & \\
\hline
\end{tabular}

Tablo 2'ye bakıldığında ergenlerde şükran duymanın cinsiyete göre anlamlı düzeyde farkl1laştığ 1 , kız öğrencilerin şükran duyma düzeylerinin $(\bar{x}=88.19)$, erkek öğrencilerin şükran duyma düzeylerinden ( $\bar{x}=83.30)$ daha fazla olduğu görülmektedir $t(601)=3.72, p<0.01$. Bu bağlamda ergenlerde şükran duygusu ile cinsiyetleri arasında anlamlı bir ilişkinin olduğu söylenebilir.

Aynı tabloda elde edilen diğer bulguya bakıldığında ergenlerde yaşam amaçları cinsiyete göre anlamlı bir fark göstermemektedir $t(601)=0.28, p<0.78$. Erkek öğrencilerin yaşam amaçları puanı $(\bar{x}=111.69)$, kız öğrencilerin puanlarına $(\bar{x}=111.30)$ göre daha fazla olmasına rağmen bu fark anlamlı bir düzeyde değildir.

Diğer bulgu olarak ergenlerde yaşam doyumu da cinsiyete göre anlamlı bir fark göstermemektedir, $t(601)=0.69, p<0.49$. K1z öğrencilerin yaşam doyum düzeyi $(\bar{x}=12.91)$, erkek öğrencilerin yaşam doyumu düzeyinden $(\bar{x}=12.67)$ daha fazla olmasına rağmen bu farkın anlamlı olmadığı görülmüştür.

2. Şükran, Yaşam Amaçları ve Yaşam Doyumu ile Sınıf Düzeyi Değişkenine Illişkin Bulgular 
Ergenlerin şükran, yaşam amaçları ve yaşam doyumlarının sınıf düzeylerine anlamlı olarak farklılaşıp farklılaşmadığını tespit için tek yönlü varyans analizi (ANOVA) uygulanmıştır. $\mathrm{Bu}$ analiz sonucunda ortaya çıkan sonuçlar tablo 3’te verilmiştir.

Tablo 3. Ergenlerin Şükran, Yaşam Amaçları ve Yaşam Doyumu Puanlarının Sınıf Düzeyi Değişkenine Göre Betimsel İstatistikleri ve ANOVA Sonuçları (N=603)

\begin{tabular}{llcccccc}
\hline & Sinıf Düzeyi & $\mathbf{n}$ & $\overline{\mathbf{x}}$ & $\mathbf{S}$ & $\mathbf{F}$ & $\mathbf{P}$ & Anlamlı Fark \\
\hline \multirow{4}{*}{ Şükran } & 1-9. Sınıf & 117 & 88.07 & 15.17 & 1.378 & .249 & Anlamlı bir \\
& 2-10. Sınıf & 159 & 85.02 & 17.37 & & & farka \\
& 3-11. Sınıf & 180 & 84.66 & 16.53 & & & rastlanmamıştır \\
& 4-12. Sınıf & 147 & 86.86 & 15.24 & & & \\
\hline \multirow{3}{*}{ Yaşam } & 1-9. Sınıf & 117 & 111.49 & 18.92 & .816 & .486 & Anlamlı bir \\
Amaçları & 2-10. Sınıf & 159 & 111.14 & 16.48 & & & farka \\
& 3-11. Sınıf & 180 & 110.41 & 16.71 & & & rastlanmamıştır \\
& 4-12. Sinıf & 147 & 113.23 & 14.69 & & & \\
Yaşam & 1-9. Sınıf & 117 & 13.64 & 4.44 & 2.653 & .052 & Anlamlı bir farka \\
Doyumu & 2-10. Sinıf & 159 & 12.98 & 4.06 & & & rastlanmamıştır \\
& 3-11. Sinıf & 180 & 12.53 & 4.22 & & & \\
\hline
\end{tabular}

$p>0.05$

Tablo 3'deki analiz sonuçlarına bakıldığında şükran duymada 9. sınıfların en yüksek ortalamaya $(\overline{\mathrm{X}}=88.07),[F(3,599)=1.378]$; yaşam amaçlarında 12. sınıfların en yüksek ortalamaya $(\overline{\mathrm{x}}=113.23), \quad[F(3,599)=0.816]$ ve yaşam doyumunda ise yine 9.sınıfların en yüksek ortalamaya ( $\overline{\mathrm{x}}=13.64), \quad[F(3,599)=2.653]$ sahip olduğu görülmektedir. Sonuçlar incelendiğinde sınıf düzeyi değişkenine göre ergenlerin şükran, yaşam amaçları ve yaşam doyumlarının anlamlı bir farka sahip olmadığı görülmektedir.

3. Şükran, Yaşam Amaçlarl ve Yaşam Doyumu ile Okul Türü Değişkenine İlişkin Bulgular

Ergenlerde şükran, yaşam amaçları ve yaşam doyumu için devam ettikleri okul türü değişkeni açısından anlamlı bir fark bulunup bulunmadığını belirlemek amacıyla ANOVA yapılmıştır. Elde edilen sonuçlar Tablo 4'de verilmiştir.

Tablo 4. Ergenlerin Şükran, Yaşam Amaçları ve Yaşam Doyumu Puanlarının Okul Türü Değişkenine Göre Betimsel İstatistikleri ve ANOVA Sonuçları (N=603)

\begin{tabular}{llcccccc}
\hline & Okul Türü & $\mathbf{n}$ & $\overline{\mathbf{x}}$ & $\mathbf{S}$ & $\mathbf{F}$ & $\mathbf{p}$ & Anlamlı Fark \\
\hline \multirow{2}{*}{ Şükran } & 1-Fen Lisesi & 148 & 91.05 & 13.47 & 18.024 & .000 & $1-3,1-4,2-3,2-4$ \\
& 2-Anadolu Lisesi & 191 & 89.03 & 14.46 & & & \\
\hline
\end{tabular}




\begin{tabular}{|c|c|c|c|c|c|c|c|}
\hline & \multirow{3}{*}{$\begin{array}{l}\text { 3-Anadolu İmam } \\
\text { Hatip Lisesi } \\
\text { 4-Mesleki ve Teknik } \\
\text { Anadolu Lisesi }\end{array}$} & & \\
\hline & & 126 & 82.47 & 16.39 & & & \\
\hline & & 138 & 79.40 & 18.16 & & & \\
\hline \multirow{4}{*}{$\begin{array}{l}\text { Yaşam } \\
\text { Amaçları }\end{array}$} & 1-Fen Lisesi & 148 & 114.16 & 16.04 & \multirow[t]{4}{*}{4.037} & \multirow[t]{4}{*}{.007} & \multirow[t]{4}{*}{$1-3$} \\
\hline & 2-Anadolu Lisesi & 191 & 112.96 & 14.49 & & & \\
\hline & $\begin{array}{l}\text { 3-Anadolu İmam } \\
\text { Hatip Lisesi }\end{array}$ & 126 & 108.32 & 17.56 & & & \\
\hline & $\begin{array}{l}\text { 4-Mesleki ve Teknik } \\
\text { Anadolu Lisesi }\end{array}$ & 138 & 109.46 & 18.51 & & & \\
\hline \multirow{4}{*}{$\begin{array}{l}\text { Yaşam } \\
\text { Doyumu }\end{array}$} & 1-Fen Lisesi & 148 & 13.96 & 4.15 & \multirow[t]{4}{*}{9.455} & .000 & \multirow[t]{4}{*}{$1-2,1-4,2-3,3-4$} \\
\hline & 2-Anadolu Lisesi & 191 & 12.17 & 3.70 & & & \\
\hline & $\begin{array}{l}\text { 3-Anadolu İmam } \\
\text { Hatip Lisesi }\end{array}$ & 126 & 13.52 & 4.53 & & & \\
\hline & $\begin{array}{l}\text { 4-Mesleki ve Teknik } \\
\text { Anadolu Lisesi }\end{array}$ & 138 & 12.80 & 4.43 & & & \\
\hline
\end{tabular}

Tablo 4'de görüldüğü gibi yapılan analiz sonuçları, okudukları okul türüne göre ergenlerin şükran duyma düzeylerinin anlamlı bir farklılığa sahip olduğunu göstermektedir $[F(3,599)=18.024, p<0.01]$. Öğrencilerin devam ettikleri okul türlerine göre farkların hangi gruplar arasında olduğunu bulmak amacıyla yapılan Scheffe testinin sonuçları, Fen Lisesi $(\bar{x}=91.05)$ ve Anadolu Lisesi $(\bar{x}=89.03)$ öğrencilerinin şükran duyma düzeylerinin Anadolu İmam Hatip Liselerinde $(\bar{x}=82.47)$ ve Mesleki ve Teknik Anadolu Liselerinde ( $\overline{\mathrm{X}}=79.40)$ eğitim gören öğrencilerden anlamlı düzeyde farklılaştığını göstermektedir.

Elde edilen analiz sonuçları, ergenlerin yaşam amaçlarının okudukları okul türüne göre de anlamlı bir şekilde farklılaştığını göstermektedir $[F(3,599)=4.037$, $p<0.01]$. Yaşam amaçlarının okul türlerine göre farkının hangi gruplar arasında olduğunu bulmak amacıyla yapılan Scheffe testinin sonuçlarına göre Fen Liselerinde $(\bar{x}=114.16)$ öğrenim gören ergenlerin yaşam amaçlarının Anadolu İmam Hatip Liselerinde $(\bar{x}=108.32)$ öğrenim gören öğrencilerden anlamlı düzeyde farkl1laştı̆̆ belirlenmiştir.

Analiz sonuçları, ergenlerin yaşam doyumlarının okudukları okul türüne göre anlamlı bir şekilde farklılaştığını göstermektedir $[F(3,599)=9.455, p<0.01]$. Farkların hangi gruplar arasında olduğunu belirlemek amaciyla yapılan Scheffe testinin sonuçlarına göre, Fen Liselerinde $(\bar{x}=13.96)$ öğrenim gören ergenlerin yaşam doyumu 
düzeylerinin Anadolu Liselerinde ( $\bar{x}=12.17)$ ve Mesleki ve Teknik Anadolu Liselerinde $(\bar{x}=12.80)$ öğretim gören ergenlerin yaşam doyumu düzeylerinden anlamlı düzeyde farklılık göstermektedir. Ayrıca Anadolu İmam Hatip Liselerinde ( $\bar{x}=13.52)$ öğrenim gören ergenlerin de yaşam doyumu düzeylerinin Anadolu Liselerinde $(\bar{x}=12.17)$ ve Mesleki ve Teknik Anadolu Liselerinde $(\bar{x}=12.80)$ öğretim gören ergenelerin yaşam doyumu düzeylerinden anlamlı düzeyde farkl1lık göstermektedir.

\section{4. Şükran, Yaşam Amaçları ve Yaşam Doyumu ile Başarı Durumu Değiş̧kenine İlişkin Bulgular}

Ergenlerde şükran, yaşam amaçları ve yaşam doyumları için en son dönemdeki karne başarı değişkeni açısından fark bulunup bulunmadığını belirlemek amacıyla ANOVA yapılmış ve buna ilişskin bulgular Tablo 6' da verilmiştir.

Tablo 6. Ergenlerin Şükran, Yaşam Amaçları ve Yaşam Doyumu Puanlarının Başarı Durumu Değişkenine Göre Betimsel İstatistikleri ve ANOVA Sonuçları (N=603)

\begin{tabular}{|c|c|c|c|c|c|c|c|}
\hline & Başarı Durumu & $\mathbf{n}$ & $\overline{\mathbf{x}}$ & $\mathbf{S}$ & $\mathbf{F}$ & $\mathbf{p}$ & $\begin{array}{l}\text { Anlaml } \\
\text { Fark }\end{array}$ \\
\hline \multirow{4}{*}{ Şükran } & 1-Zayıfı olmak & 114 & 80.12 & 17.22 & 10.337 & .000 & $1-3,1-4,2-4$ \\
\hline & 2-Zayıfsız geçmek & 87 & 84.58 & 15.48 & & & $3-4$ \\
\hline & 3-Teşekkürle geçmek & 240 & 85.98 & 16.12 & & & \\
\hline & 4-Takdirle geçmek & 162 & 90.77 & 14.60 & & & \\
\hline \multirow{4}{*}{$\begin{array}{l}\text { Yaşam } \\
\text { Amaçları }\end{array}$} & 1-Zayıfı olmak & 114 & 107.76 & 17.60 & 3.677 & .012 & $1-4$ \\
\hline & 2-Zayıfsız geçmek & 87 & 109.83 & 16.58 & & & \\
\hline & 3-Teşekkürle geçmek & 240 & 112.09 & 16.09 & & & \\
\hline & 4-Takdirle geçmek & 162 & 114.10 & 16.36 & & & \\
\hline \multirow{4}{*}{$\begin{array}{l}\text { Yaşam } \\
\text { Doyumu }\end{array}$} & 1-Zayıfı olmak & 114 & 11.99 & 4.23 & 3.330 & .019 & $1-4$ \\
\hline & 2-Zayıfsız geçmek & 87 & 12.74 & 4.22 & & & \\
\hline & 3-Teşekkürle geçmek & 240 & 12.68 & 4.33 & & & \\
\hline & 4-Takdirle geçmek & 162 & 13.59 & 4.09 & & & \\
\hline
\end{tabular}

Analiz sonuçları (Tablo 6), başarı durumlarına göre katılımcı ergenlerin şükran duyma düzeylerinin anlamlı bir farklılığa sahip olduğunu göstermektedir, $[F(3,599)=10.337, p<.01]$. Ergenlerin son aldıkları karnedeki başarı durumlarına göre farkların hangi gruplar arasında olduğunu belirlemek amacıyla yapılan Scheffe testinin sonuçları takdir alan öğrencilerin şükran düzeyinin $(\bar{x}=90.77)$ zaylfi olan $(\bar{x}=80.12)$, zaylfsız geçen $(\bar{x}=84.58)$ ve teşekkür belgesi alan $(\bar{x}=85.98)$ öğrencilerin şükran 
düzeyinden anlamlı farklılık gösterdiği bulunmuştur. Ayrıca teşekkür belgesi alan öğrencilerin şükran düzeyi $(\bar{x}=85.98)$ ile zayıfi olan öğrencilerin şükran düzeyi $(\bar{x}=80.12)$ arasında da anlamlı bir fark olduğu belirlenmiştir.

Ergenlerin başarı düzeylerine göre yaşam amaçları puanlarının anlamlı bir şekilde farklılaştı̆̆ belirlenmiştir $[F(3,599)=3.677, p<0.05]$. Yaşam amaçlarının başarı düzeyine göre farkının hangi gruplar arasında olduğunu bulmak amacıyla yapılan Scheffe testinin sonuçlarına göre takdir belgesi alarak geçen öğrencilerin $(\bar{x}=114.10)$ yaşam amaçlarının zayıfi olan ergenlere $(\bar{x}=107.76)$ göre anlamlı düzeyde farklılaştığ belirlenmiştir.

Son olarak, katılımcıların başarı düzeylerine göre yaşam doyumları arasında anlamlı bir farklılaşma olup olmadığına bakılmış ve gruplar arasında anlamlı bir farklılaşma olduğu belirlenmiştir, $[F(3,599)=3.330, p<0.05]$. Yaşam doyumunun başarı düzeyine göre farkının hangi gruplar arasında olduğunu bulmak amacıyla yapılan Scheffe testinin sonuçlarına göre takdir alarak geçen $(\bar{x}=13.59)$ ergenlerin yaşam amaçlarının zayıfı olanlara ( $\bar{x}=11.99)$ göre anlamlı düzeyde farklılaştığı belirlenmiştir.

\section{5. Şükran, Yaşam Amaçları ve Yaşam Doyumu ile Ailenin Gelir Durumu Değişkenine İlişkin Bulgular}

Ergenlerin şükran düzeyi, yaşam doyumu ve yaşam amaçları için ailenin gelir durumuna değişkeni açısından anlamlı fark bulunup bulunmadığını belirlemek amacıyla ANOVA yapılmış ve buna ilişkin bulgular Tablo 7'de verilmiştir.

Tablo 7. Ergenlerin Şükran, Yaşam Amaçları ve Yaşam Doyumu Puanlarının Ailenin Gelir Durumu Değişkenine Göre Betimsel İstatistikleri ve ANOVA Sonuçları (N=603)

\begin{tabular}{lllccccc}
\hline & Gelir Durumu & $\mathbf{n}$ & $\overline{\mathbf{x}}$ & $\mathbf{S}$ & $\mathbf{F}$ & $\mathbf{p}$ & $\begin{array}{l}\text { Anlaml } \\
\text { Fark }\end{array}$ \\
\hline \multirow{3}{*}{ Şükran } & $\mathbf{1 - 0 - 1 6 0 3 ~ T L ~ a r a s ı ~}$ & 269 & 83.32 & 16.76 & 5.131 & .002 & $1-2,1-3$, \\
& 2-1604-2800 TL arası & 176 & 88.20 & 14.56 & & & \\
& 3-2801-4000 TL arası & 94 & 89.53 & 14.98 & & & \\
& 4-4001 TL ve üzeri & 64 & 85.56 & 18.28 & & & \\
\hline \multirow{3}{*}{ Yaşam } & 1-0-1603 TL arası & 269 & 109.06 & 16.18 & 5.495 & .001 & $1-4$ \\
Amaçları & 2-1604-2800 TL arası & 176 & 112.06 & 16.15 & & & \\
& 3-2801-4000 TL arası & 94 & 112.99 & 17.46 & & & \\
& 4-4001 TL ve üzeri & 64 & 117.87 & 16.86 & & & \\
\hline
\end{tabular}




\begin{tabular}{cllllc}
\hline & 1-0-1603 TL aras1 & 269 & 11.62 & 4.18 & 16.499.000 1-2, 1-3, 1-4, \\
Yaşam & 2-1604-2800 TL aras1 & 176 & 13.29 & 3.91 & $2-4$ \\
Doyumu & 3-2801-4000 TL aras1 & 94 & 13.67 & 4.18 & \\
& 4-4001 TL ve üzeri & 64 & 15.12 & 4.13 & \\
\hline
\end{tabular}

Tablo 7'de görüldüğü gibi elde edilen analiz sonuçlarına göre ergenlerin ailelerinin gelir durumlarına göre şükran duyma düzeyleri arasında anlamlı bir farklılık olduğu saptanmıştır $[F(3,599)=5.131, p<0.01]$. Gelir düzeyleri dikkate alındığında farkların hangi gruplar arasında olduğunu bulmak amacıyla yapılan Scheffe testinin sonuçlarına göre gelirlerinin 0-1603 TL arası $(\bar{x}=83.32)$ olduğunu belirten ergenlerin şükran duyma düzeylerinin, gelirlerinin 1604-2800 TL arası $(\bar{x}=88.20)$ ve 2801-4000 TL arası $(\bar{x}=89.53)$ olduğunu belirten ergenlerden anlamlı düzeyde farklılık gösterdiği bulunmuştur.

$\mathrm{Bu}$ tabloda verilen ikinci analiz sonuçları, ergenlerin ailelerinin gelir durumuna göre yaşam amaçları düzeyinde anlamlı bir farklılık olduğunu göstermektedir $[F(3,599)=5.495, p<0.01]$. Gelir düzeylerine göre farkların hangi gruplar arasında olduğunu bulmak amacıyla yapılan Scheffe testinin sonuçlarına göre gelirlerinin 0-1603 $T L$ arası olduğunu belirten ergenlerin yaşam amaçları düzeylerinin ( $\bar{x}=109$. 06) gelirlerinin $4000 T L$ ve üzeri olduğunu belirten ergenlerden ( $\bar{x}=117.87)$ anlamlı düzeyde farklılaştığı görülmektedir.

Aynı tabloda yer alan diğer analiz sonuçların bakıldığında, ergenlerin ailelerinin gelir durumuna göre yaşam doyumu düzeylerinin anlamlı bir şekilde farklılaştığını göstermektedir, $[F(3,599)=16.499, p<0.01]$. Gelir düzeylerine göre farkların hangi gruplar arasında olduğunu saptamak amacıyla yapılan Scheffe testinin sonuçlarına göre; aile gelirlerinin 0-1603 TL arasında olduğunu belirten ergenelerin şükran duyma düzeyleri ( $\bar{x}=11.62)$ ile gelirlerinin 1604-2800 TL arasında olduğunu belirten ergenelerin şükran duyma düzeyleri ( $\bar{x}=13.29)$, gelirleri 2801-4000 TL arası olan ergenelerin şükran duyma düzeyleri $(\bar{x}=13.29)$ ve gelirlerinin 4000 TL ve üzeri olan ergenelerin şükran duyma düzeyleri $(\bar{x}=15.12)$ arasında anlamlı bir fark olduğu belirlenmiştir. Ayrıca gelirlerinin 1604-2800 TL arasında olduğunu belirten ergeneler $(\bar{x}=13.29)$ ile gelirlerinin $4000 T L$ ve üzeri olduğunu belirten ergenlerin $(\bar{x}=15.12)$ şükran duyma düzeyleri arasında da anlamlı bir fark olduğu bulunmuştur. 
6. Şükran, Yaşam Doyumu, Yaşam Amaçları ve Yaşam Amaçları Alt Boyutları Değişkenlerine İlişkin Korelasyon Bulguları

Ergenlerin şükran duyma, yaşam doyumu ve yaşam amaçları toplam puanı ile yaşam amaçları alt boyutlarının puanları arasındaki ilişkiye bakılmış ve buna ilişkin bulgular aşağıda Tablo 5’te verilmiştir.

Tablo 5. Ergenlerin Şükran, Yaşam Doyumu, Yaşam Amaçları ve Yaşam Amaçlarının Alt Boyutlarına İlişkin Korelasyonlar ( $\mathrm{N}=603$ )

\begin{tabular}{|c|c|c|c|c|c|c|c|c|}
\hline & 1 & 2 & 3 & 3.a. & 3.b. & 3.c. & 3.d. & 3.e. \\
\hline 1. Şükran & 1 & $.439^{* *}$ & $.383^{* *}$ & $.492^{* *}$ & $\begin{array}{l}-.066 \\
\end{array}$ & .072 & $.495^{* *}$ & $.416^{* *}$ \\
\hline 2. Yaşam Doyumu & & 1 & $.242^{* *}$ & $.207^{* *}$ & .070 & $.156^{* *}$ & $.197^{* *}$ & $.197^{* * *}$ \\
\hline 3. Yaşam Amaçları & & & 1 & $.721^{* *}$ & $.595^{* *}$ & $.695^{* *}$ & $.615^{* *}$ & $.610^{* *}$ \\
\hline 3.a. Kişisel Gelişim & & & & 1 & .015 & $.210^{* *}$ & $.629^{* *}$ & $.563^{* *}$ \\
\hline 3.b. Maddi Kazanç & & & & & 1 & $.581^{* *}$ & -.021 & .047 \\
\hline 3.c. Fiziksel Görünüm & & & & & & 1 & $.143^{* *}$ & $.160^{* *}$ \\
\hline 3.d. Sosyal Sorumluluk & & & & & & & 1 & $.549^{* *}$ \\
\hline 3.e.Bireysel Farkındalık & & & & & & & & 1 \\
\hline
\end{tabular}

Tablo 5 incelendiğinde Şükran ile diğer değişkenler arasındaki korelasyonların 0.066 ile 0.492 arasında değerler aldığı görülmektedir. Şükran ile Yaşam Doyumu arasında $r=0.44$, Şükran ile Yaşam Amaçları arasında $r=0.383$, Şükran ile Yaşam Amaçları alt boyutlarından Kişisel Gelişim arasında $\mathrm{r}=0.492$, Şükran ile Sosyal Sorumluluk arasında $r=0.495$ ve Şükran ile Bireysel Farkındalık arasında $r=0.416$ düzeyinde pozitif yönde ilişki olduğu bulunmuştur. Şükran ile Maddi Kazanç arasında negatif yönde ( $r=-0.066)$ ve Şükran ile Fiziksel Görünüm arasında ise positif yönde düşük düzeyde ilişki olduğu saptanmıştır $(r=0.072)$.

Yaşam Doyumu ile diğer değişkenler arasındaki korelasyonların 0.070 ile 0.242 arasında değerler aldığı görülmektedir. Yaşam Doyumu ile Yaşam Amaçları arasında r= 0.242, Yaşam Doyumu Yaşam Amaçları alt boyutları olan Kişisel Gelişim arasında $r=$ 0. 207, Yaşam Doyumu ile Fiziksel Görünüm arasında $r=0.156$, Yaşam Doyumu ile Sosyal Sorumluluk arasında $r=0.156$ ve Yaşam Doyumu ile Bireysel Farkındalık arasında $r=0.197$ düzeyinde pozitif yönde ilişki olduğu bulunmuştur. En düşük ilişkinin Yaşam Doyumu ile Maddi Kazanç arasında olduğu saptanmıştır ( $r=0.070)$.

Yaşam Amaçları ile Yaşam Amaçları alt boyutlarının oluşturduğu değişkenler arasındaki korelasyonların 0.595 ile 0.721 arasında değerler aldığı görülmektedir. Yaşam Amaçları ile Kişisel Gelişimi arasında r= 0.721, Yaşam Amaçları ile Maddi Kazanç 
arasında $r=0.595$, Yaşam Amaçları ile Fiziksel Görünüm arasında $r=0$. 695, Yaşam Amaçları ile Sosyal Sorumluluk arasında $r=0.615$, Yaşam Amaçları ile Bireysel Farkındalık arasında pozitif yönde $r=0.610$ düzeyinde ilişski olduğu bulunmuştur.

Yaşam Amaçlarının alt boyutlarından olan Kişisel Gelişim ile Yaşam Amaçlarının diğer alt boyutlarının oluşturduğu değişkenler arasındaki korelasyonların 0.015 ile 0.629 arasında değerler aldığı görülmektedir. Kişisel Gelişim ile Maddi Kazanç arasında $\mathrm{r}=0.015$, Kişisel Gelişim ile Fiziksel Görünüm arasında $r=0.210$, Kişisel Gelişim ile Sosyal Sorumluluk arasında $r=0.629$, Kişisel Gelişim ile Bireysel Farkındalık arasında $\mathrm{r}=0.563$ düzeyinde pozitif yönde ilişki olduğu bulunmuştur.

Yaşam Amaçlarının alt boyutlarından olan Maddi Kazanç ile Yaşam Amaçlarının diğer alt boyutlarının oluşturduğu değişkenler arasındaki korelasyonların 0.021 ile 0.581 arasında değerler aldığı görülmektedir. Maddi Kazanç ile Fiziksel Görünüm arasında $r=0.581$, Maddi Kazanç ile Bireysel Farkındalık arasında $r=0.047$ düzeyinde pozitif yönde ilişki olduğu, Maddi Kazanç ile Sosyal Sorumluluk arasında ise negatif yönde düşük düzeyde ilişki olduğu bulunmuştur ( $r=0.021)$.

Yaşam Amaçlarının alt boyutlarından olan Fiziksel Görünüm ile Yaşam Amaçlarının diğer alt boyutlarından biri olan Sosyal Sorumluluk arasında $r=0.143$, Fiziksel Görünüm ile Bireysel Farkındalık arasındaki r= 0.160 düzeyinde pozitif yönde ilişki olduğu bulunmuştur.

Yaşam Amaçlarının alt boyutlarından olan Sosyal Sorumluluk ile Bireysel Farkındalık arasında $r=0.549$ düzeyinde pozitif yönde ilişki olduğu saptanmıştır.

7. Ergenlerde Şükran, Yaşam Amaçlarl ve Yaşam Doyumunun Yordanmasına İlişkin Regresyon Analizi Bulguları

Yaşam doyumunun şükran ve yaşam amaçları alt boyutları tarafından ne oranda yordandığını belirlemek amacıyla çoklu regresyon analizi türlerinden aşamalı regresyon analizine başvurulmuştur. Buna ilişsin sonuçlar Tablo 8‘de verilmektedir.

Tablo 8. Ergenlerin Yaşam Doyumunun Yordanmasına İlişkin Aşamalı Regresyon Analizi Sonuçları

\begin{tabular}{llllll}
\hline Model & Yordayıc1 & $\mathrm{B}$ & $\mathrm{SH}$ & $\beta$ & $\Delta \mathrm{R}^{2}$ \\
\hline 1 & Şükran & .12 & .01 & $.44^{* *}$ & $.19^{* *}$ \\
& Sabit & 2.90 & .84 & & \\
\hline 2 & Şükran & .11 & .01 & $.43^{* *}$ & $.02^{* *}$ \\
& Fiziksel Görünüm Boyutu & .10 & .03 & $.13^{* *}$ & \\
& Sabit & 1.27 & .96 & & \\
\hline
\end{tabular}


${ }^{*} \mathrm{p}<.05 \quad{ }^{* *} \mathrm{p}<.01$

Aşamalı regresyon analizinde her bir bağımsız değişken eşitlikteki kendi giriş sırası bakımından ne eklendiğine göre belirlenmektedir (Tabachnick ve Fidell, 2001). Burada da yordanan değişken (yaşam doyumu) ile yordayıcı değişkenler (şükran ve yaşam amaçları alt boyutları) arasındaki ilişkiye bakılmış ve açıklanan varyansın ya da ilişkiye ait regresyon modelinin istatistiksel olarak anlamlı olduğu görülmüştür [Şükran toplam, $F(1,601)=143.568, \quad p<.01$; Şükran toplam ve Fiziksel görünüm boyutu $F(2,600)=79.003, p<.01]$.

Analiz iki aşamada tamamlanmıştır. Birinci aşamada incelenen şükran değişkeninin tek başına ergenlerin yaşam doyumunu yordamada standardize edilmiş regresyon katsayısı (Beta) 0.439 bulunmuştur. Tek başına şükran değişkeninin ergenlerin yaşam doyumlarının \% 19 kadarını $(\mathrm{R}=0.439, \quad \mathrm{R} 2=0.193)$ açıkladığı görülmektedir. Aşamalı regresyon analizinin ikinci adımında modele şükran değişkeninin yanında fiziksel görünüm değişkeni dahil olmuştur. Elde edilen sonuç; Şükran ile Fiziksel Görünüm değişkenlerinin birlikte ergenlerde Yaşam Doyumunun \% 21'ini (R=0.457, R2=0.208) anlamlı düzeyde olduğunu açıklamaktadır. Regresyon katsayıları incelendiğinde, aşamalı regresyon analiz sonuçlarına göre modele alınan Yaşam Amaçlarının diğer alt boyutlarının (Kişisel Gelişim, Maddi Kazanç, Sosyal Sorumluluk, Bireysel Farkındalık) Yaşam Doyumunu yordamada önemli herhangi bir etkiye sahip olamadığı tespit edilmiştir.

\section{Tartışma ve Sonuç}

Bu çalışmada önce ergenlerin şükran, yaşam amaçları ve yaşam doyumunun cinsiyete göre değişip değişmediğine bakılmıştır. Elde edilen bulgulara göre şükran düzeyleri açısından kız ve erkek öğrenciler arasında anlamlı bir fark olduğu ve kızların erkeklere göre daha yüksek düzeyli şükran eğilimine sahip oldukları görülmektedir. Bu sonuca bakarak Türkiye'de anne babaların kız ve erkek çocuklarını büyütürken onları farklı şekilde yetiştirme eğiliminde oldukları söylenebilir. Literatür incelendiğinde, Kashdan Mishra, Breen ve Froh (2009) tarafından üniversite öğrencilerine yönelik yapılan bir çalışmada da bireylerin şükranlarını ifade etmelerinde cinsiyete göre bir fark olduğu görülmüş ve bu farkın kadınların lehine olduğu da tespit edilmiştir. Şükran duygusu bireyin kişisel ve sosyal iyi oluşuyla (Kardaş ve Yalçın, 2018), kendisine 
faydası olan kişiye karşı minnet duymayı sağlaması (Emmons, 2004) ve yaşamın anlamını gerçekleştirmesinde payı olduğu (Datu ve Mateo, 2015) için tüm bireyler için önemlidir.

Yaşam amaçları ve yaşam doyumu açılarından kız ve erkek öğrenciler arasında anlamlı bir farka rastlanamamıştır. Bu dönemde gerek kız gerekse erkeklerin daha çok fiziksel, psikolojik ve sosyal yöndeki gelişim ve değişime uyum gösterme çabaları yaşam amaçları ve yaşam doyumlarının önüne geçmiş olabilir. Alan yazına bakıldığında bazı çalışmalarda cinsiyet değişkeninin yaşam amaçlarını anlamlı düzeyde etkilediği görülmektedir. İlhan ve Özbay (2010) ve Demirtaş Çelik (2016) üniversite öğrencilerine yönelik yaptıkları çalışmalarda cinsiyetin yaşam amacını etkileyen bir faktör olduğunu bulmuşlardır (Demirtaş Çelik, 2016; İlhan ve Özbay, 2010).

Yaşam doyumu ile ilgili 15- 21 yaş arasındaki ergenlerle yapılan bir çalışmada (Erturan ve ark., 2014) ve yine lise düzeyindeki ergenlerle yapılmış diğer çalışmalarda (Kermen ve diğ., 2016; Telef, 2013) yaşam doyumunun cinsiyet değişkenine göre anlamlı bir fark göstermediği belirlenmiştir.

Araştırmada ergenlerin şükran, yaşam amaçları ve yaşam doyumu düzeylerinin bulundukları sınıf düzeyine göre anlamlı bir farklılık göstermediği bulunmuştur. Sınıf düzeylerine göre farkın çıkmamasına katılımcıların çoğunun aynı sosyo-ekonomik statüye sahip ailelerden geliyor olması ve yaşları itibariyle aynı gelişimsel dönem içinde yer almalarının etkili olduğu düşünülmektedir. Telef'in (2013) yaşam doyumuna dair yapmış olduğu çalışmada lisede okuyan öğrencilerin yaşlarının anlamlı bir fark oluşturduğu belirtmiş ve oluşan farkın hangi gruplar arasında olduğuna bakıldığında 15 yaşındaki ergenlerin yaşam doyumunun 16, 17 ve 18 yaşındaki ergenlerin yaşam doyumundan daha yüksek olduğu bulgusuna ulaşılmıştır (Telef, 2013).

Ergenlerin öğrenim gördükleri okullara göre şükran, yaşam doyumu ve yaşam amaçlarına göre en belirgin farkın Fen Lisesi öğrencileri ile Mesleki ve Teknik Anadolu Lisesi öğrencileri arasında olduğu görülmektedir. Şükran düzeyi Fen Lisesi ve Anadolu Liselerinde öğrenim gören öğrencilerde daha yüksektir.

Farklı liselere devam eden ergenlerin yaşam amaçları düzeyleri karşılaştırıldığında Fen Lisesi öğrencileri ile Anadolu İmam Hatip Lisesi öğrencileri arasında anlamlı bir fark olduğu görülmektedir. Yaşam amaçları en yüksek öğrenciler Fen Lisesine devam öğrencilerdir. 
Yaşam doyumu düzeyleri açısından Fen Lisesi ve Anadolu İmam Hatip Lisesi öğrencilerin daha yüksek doyuma sahip oldukları görülmüştür. Fen lisesini kazanan öğrencilerin başarı düzeylerinin en yüksek öğrenciler olması ve Anadolu İmam Hatip Lisesi öğrencilerinin gördükleri derslerde maneviyata dair içerik yaşam doyumlarını arttırdığı söylenebilir. Telef'in (2013) lise öğrencileri ile yaptığı çalışmada okul türlerine göre yaşam doyumu düzeylerinde anlamlı bir farklılığa rastlanamadığ 1 görülmektedir.

Ergenlerin şükran, yaşam amaçları ve yaşam doyumu düzeylerinin başarı durumlarına göre farklılaştığı görülmektedir. Takdir belgesi alan öğrencilerin şükran düzeyi diğer gruptaki öğrencilerden anlamlı bir şekilde farklılaşmaktadır. Takdir belgesi alan öğrencilerin şükran puanları diğer öğrencilerin şükran puanlarından yüksek çıkmıştır. Aynı şekilde teşekkür belgesi alan öğrencilerin de şükran puanı karnesinde zayıfı olan öğrencilerin puanlarından anlamlı düzeyde farklılaşmakta olduğu görülmüştür. Şükran elde edilen bir şeyden lezzet almak, verilen şeyleri hakkı gibi görmeme ve karşılığında minnettarlık hissetme, baş etme ve şimdi odaklı olmaktır (Kardaş ve Yalçın, 2018). Şükran duyan bireyler daha an'a odaklı, daha başarılı ve sahip olduklarından dolayı tatmin duygusu yaşayan, ayrıca sahip olduklarını kendi olmazsa olmazı olarak da görmeyen kişilerdir. Olumlu olan her şeyi hak ettiklerini düşünen bireylerin şükran duyma düzeyi daha düşük olmaktadır (Kardaş ve Yalçın, 2018). Bu nedenlerle başarılı öğrencilerin daha az başarılı olan öğrencilere göre sahip olduklarına dair farkındalıklarının yüksek olduğu ve bunlar için minnet duydukları söylenebilir. Yaptıkları işlerde belirlenen kriterlere göre başarı sergileyen bireylerin şükran duygusuna sahip olması beklenen bir durum olarak görülmektedir. Akademik başarının çok önemli olduğunun vurgulandığı ve kabul edildiği günümüzde derslerinde başarılı olamayan öğrencilerin kendilerini rahat hissedemeyip şükran duygularının da bundan da olumsuz yönde etkilediği söylenebilir.

Ergenlere, yaşam amaçları ve yaşam doyumları açılarından bakıldığında ise başarı düzeyi yüksek olanlar ile başarı düzeyi en düşük düzeyde olanlar arasında anlamlı fark olduğu görülmüştür. Yaşam amacı puanları daha yüksek olan başarılı öğrencilerin hedeflerinde daha net oldukları ve bu doğrultuda çabaladıkları söylenebilir. En başarılı grup yaşam doyumu noktasında da başarısız olan gruba göre yüksek puanlar almıştır. Bireylerin başarı düzeyleri yükseldikçe yaşam doyumunun da artmakta olduğu 
söylenebilir. Çalışmada yer alan lise türlerine göre yaşam doyumu puanları en yüksek puanla öğrenci alan Fen Liseleri ile daha az puanla öğrenci alan liselere devam edenler arasında farklılık görülmektedir. Fen liselerine devam eden öğrenciler daha yüksek yaşam doyumuna sahip bulunmuşlardır. Bu bulgu başarılı olma ile yaşam doyumu arasında pozitif yönde anlamlı bir ilişkiye işaret etmektedir.

Ergenlerin ailelerinin gelir durumuna göre şükran, yaşam amaçları ve yaşam doyumları arasındaki farklara bakıldığında şükran düzeyi en yüksek olan bireylerin orta gelir grubunda yer alan bireyler olduğu görülmektedir. Beklendiği gibi en düşük gelir grubunda yer alan öğrenciler en düşük şükran düzeyine sahiptirler. Ancak görece aileleri yüksek gelir düzeyine sahip olan ergenlerin şükran düzeyinin düşük olması dikkat çeken bir bulgu olarak görülmektedir. Chow’a (2005) göre sosyo-ekonomik durum yaşam doyumuna etki eden faktörlerden birisidir. Gündoğar ve ark. (2007) yaptıkları bir çalışmada ekonomik durumları iyileştikçe bireylerin yaşam doyumunun artmakta olduğunu bulmuşlardır. Bulgulara bakıldığında bireylerin yaşam doyumlarının artmasının, gelir düzeylerinin yükselmesiyle bağlantılı olduğu söylenebilir. Yaşam amaçları açısından bakıldığında ise en düşük gelir seviyesinde yer alan bireylerin en yüksek gelir seviyesinde yer alan bireylerden farklılık gösterdiği bulunmuştur.

Araştırmada Şükran ile Yaşam Doyumu, Yaşam Amaçları ve Yaşam Amaçları alt boyutlar arasındaki ilişkilere bakıldığında; Şükran ile Yaşam Doyumu, Yaşam Amaçları ve yaşam amaçları alt boyutlarından Sosyal Sorumluluk ve Bireysel Farkındalık ile aralarında orta düzeyde pozitif yönde anlamlı ilişkilerin olduğu görülmektedir. Şükran ile yaşam amaçları alt boyutlarından Maddi Kazanç ile (negatif yönde) düşük ve yine Fiziksel Görünüm ile (pozitif yönde) düşük yönde bir ilişki olduğu bulunmuştur. Bu bulgu bazı literatür bulgularıyla benzerlik göstermektedir.

Szczesniak ve Soares'in (2011) yapmış oldukları bir çalışmada şükran, umut ve geleceğe dair iyimserliğin yüksek düzeyde ve pozitif yönlü yaşam doyumuyla ilişkili olduğu bulunmuştur. Datu ve Mateo (2015) da çalışmalarında şükran ile yaşam doyumu ve yaşamdaki anlam arasında orta düzeyde ve pozitif bir ilişkiye rastlamışlardır. Eryılmaz (2014) şükran ifade etmenin kişinin yaşam doyumu ve olumlu duygularının artmasına katkıda bulunduğunu belirtmektedir. Araştırmada şükran ile yaşam amaçlarının alt boyutlarından Maddi Kazanç ve Fiziksel Görünüm arasında anlamlı bir 
ilişkiye rastlanmamıştır. Lyubomirsky (2008) göre şükran duygulanımının kişinin amaçlarına göre değişebilmektedir.

Elde edilen bulgulara göre bireylerin maddiyata ve fiziksel görünüme dair hedeflerinin şükran duymada herhangi bir etkisinin bulunmadığı: kişisel gelişim, sosyal sorumluluk ve bireysel farkındalık gibi alt boyutlar ile şükran arasında pozitif ve anlamlı bir ilişki olduğu söylenebilir. Kasser ve Ryan (2001) göre yaşam amaçları içsel ve dışsal diye ikiye ayrılmaktadır. İçsel yaşam amaçları kategorisine dahil edilebilecek olan kişisel gelişim, sosyal sorumluluk ve bireysel farkındalık gibi amaçlara sahip bireylerin daha fazla yaşam doyumu ve mutluluk duygusu (Kasser ve Ryan, 1996) yaşadıkları belirtilmiştir.

Yapılan aşamalı regresyon analizi sonucunda ergenlerde Şükran ve yaşam amaçları birlikte yaşam doyumunu \% 21 düzeyinde açıkladığı bulgusuna ulaşılmıştır. Şükranın tek başına yaşam doyumunu \% 19'unu yorduyor olması ise önemli bir bulgu olarak değerlendirilmektedir. Alanyazında yapılan bazı çalışmaların bu bulguyu desteklediği görülmektedir. Datu ve Mateo’nun (2015) yaş ortalamas1 17.6 olan 400 üniveriste öğrencileriyle yaptıkları çalışmalarında şükran ve yaşamın anlamı birlikte yordayıcı olarak atandığında yaşam doyumunu \%44 oranında açıkladığı, ancak şükranın tek başına yordayıcı olarak yaşam doyumunu \%26 oranında katkı sağladığı bulunmuştur. Park, Peterson, \& Seligman (2004) tarafından yetişkinlere ve gençlere yönelik yapılan bir çalışmada katılımcıların yaşam doyumu lezzet, şükran, umut ve sevgi tarafında yüksek düzeyde açıklanmakta olduğu bulgusuna ulaşılmıştır (Akt: Seligman, Steen, Park ve Peterson, 2005). Froh, Sefick ve Emmons'un (2008) 11-14 yaşları arasındaki ergenlerle yaptıkları çalışmada şükran duygularını ifade eden ergenlerin iyimserlik ve yaşam doyumu düzeylerinin diğer ergenlere göre daha yüksek olduğu görülmüştür. Şükran duymanın; anlamlı bir yaşam sürdürme eğilimini artıracağı ve hayatın amacı ile bağlantılı olduğu (Froh ve Bono, 2008; Akt: Datu, 2014) belirten çalışmalarda bulunmaktadır.

\section{Öneriler}

Araştırmada erkek öğrencilerin şükran duygusunun kız öğrencilere göre anlamlı düzeyde düşük olduğu bulunmuştur. Şükran duyma düzeyi arttıkça öğrencilerin başarı düzeyi, yaşam amaçları ve yaşam doyumunun yükseldiği göz önüne alındı̆̆ında; yapılacak rehberlik ve psikolojik danışma faaliyetleri içerisinde erkek öğrencilerin 
şükran duyma düzeylerini arttırıcı çalışmalara yer verilebilir. Örneğin, öğrencilerin toplum içinde karşılaştıkları iyi durumları ifade edip bunlarla ilgili minnettarlıklarını ifade etmelerine yardımcı olacak "atılganlık” ve benzeri grup etkinliklerinin teşvik edilmesi bu bağlamada faydalı görülmektedir.

Ergenlerin devam ettiği okul türü onların şükran, yaşam amaçları ve yaşam doyumlarını etkilediği görülmektedir. Ergenler için okullarını çekici kılacak konularda çalışmalar yapmak onların okulunu benimsemesi ve dolayısıyla akademik olarak motivasyonlarını ve başarılarını destekleyecektir. Örneğin okulların çeşitli akademik, sosyal ve kültürel olanaklarının bulunması ileri düzeyde bir eğitim için önemli bir firsat sağlayabilir. Bu tür özellikler okulun çekiciliğini arttırabilir ve öğrencilerin kendilerini iyi hissetmelerinde etkili olabilir. Özellikle Mesleki ve Teknik Anadolu Liselerinde öğrenim gören öğrencilerin bütün alanlarda düşük puanlar almaları ve diğer liselerle farklılıklar gösteriyor olmaları, bu alanda yapılacak çalışmalarda öncelikle ele alınması gereken lisenin bu liseler olduğu fikrini oluşturmuştur

Aynı şekilde akademik başarısı düşük olan öğrencilerin başarı düzeylerini artıracak müdahale programlarına şükran eğitiminin ve yaşam amaçları belirleme çalışmaları eklenebilir.

Ailesinin ekonomik düzeyi düşük olan öğrencilerin şükran, yaşam amaçları ve yaşam doyumlarının düşük olduğu görülmektedir. Çeşitli devlet kurumları ile temasa geçilerek okullarda maddi durumu iyi olmayan öğrencilerin ailelerine maddi destek sağlamak ergenlerin kendilerini daha iyi hissetmelerine imkan verecektir. İnsanın ruhsal iyi oluşunu belirleyen önemli kavramlardan olan Şükran, Yaşam Doyumu ve Yaşam Amaçları arasında anlamlı ilişkiler olduğu görülmektedir. $\mathrm{Bu}$ gibi kavramlara dayalı ergenler ve anne babalarına yönelik çalışmalar ergenlerin psikolojik gelişimlerini destekleyebilir.

İleride, araştırmacılar farklı bölgelerde yaşayan ergenler üzerinde çalışarak şükran, yaşam doyumu ve yaşam amaçları bakımlarından aralarındaki benzerlik ya da farklılıklar ortaya çıkarabilir. Ayrıca farklı eğitim basamaklarına uygun şükran, yaşam doyumu ve yaşam amaçları konularında programlar hazırlanarak öğrenciler üzerindeki etkilerini belirleyici çalışmalar yapılabilir. 


\section{Sinırlılıklar}

Van ili merkez okullarında yapılan bu çalışma her ne kadar evreni temsil etmek için gerekli olan sayıya sahip olsa da, sonuçların genellenebilirliği açısından farklı bölgelerdeki illerde liseye devam eden ergenlerin içinde olduğu bir çalışmaya göre sınırlılık arz etmektedir. Aynı zamanda öğrencilerin kendilerine verilen test bataryasına samimi cevaplar verdiği varsayılmıştır.

\section{Makalenin Bilimdeki Konumu}

Eğitim Bilimleri Bölümü/ Rehberlik ve Psikolojik Danışmanlık Alanı

\section{Makalenin Bilimdeki Özgünlüğü}

Literatür incelendiğinde ergenlerde şükran durumunu yaşam doyumu ve yaşam amaçları ile birlikte inceleyen herhangi bir çalışmaya rastlanamamıştır. Şükran duyma durumu olumlu tepkilerle karşılanan iyi bir özellik olarak görülmektedir. Şükran duymanın, kişiye bir şeyleri takdir edebilme ve sahip olduklarıyla mutlu olabilme gibi pozitif özellikler katarak bireylerin yaşam doyumunun artmasına ve mutlu olmasına katkıda bulunacağı varsayılmaktadır.

\section{Kaynaklar}

Austin, J.T. \& Vancouver, J.B. (1996). Goal constructs in psychology: Structure, process, and content. Psychological Bulletin, 120(3), 338-375.

Aydıner, B. B. (2011). Üniversite öğrencilerinin yaşam amaçlarının alt boyutlarının genel öz-yeterlik, yaşam doyumu ve çeşitli değişkenlere göre incelenmesi (Yayınlanmamış Yüksek lisans tezi). Sakarya Üniversitesi Eğitim Bilimleri Enstitüsü, Sakarya.

Carr, A. (2016). Pozitif Psikoloji. (Çev. Ümit Şendilek). İstanbul: Kaknüs Yayınları

Cenkseven, F. ve Akbaş, T. (2007). Üniversite öğrencilerinde öznel ve psikolojik iyi olmanın yordayıcılarının incelenmesi. Türk Psikolojik Danışma ve Rehberlik Dergisi, 3 (27), 43-65.

Chow, H.P.H. (2005). Life satisfaction among university students in a Canadian prairie city: a multivariate analysis. Social Indicators Research, 70, 139-150.

Çam, Z. ve Artar, M.(2014). Ergenlikte yaşam doyumu: Okul türleri bağlamında bir inceleme. Muş Alparslan Üniversitesi Sosyal Bilimler Dergisi, 2(1), 23-46. 
Dağl1, A. ve Baysal, N. (2016). Yaşam Doyumu Ölçeğinin Türkçe'ye uyarlanması: Geçerlik ve güvenirlik çalışması. Elektronik Sosyal Bilimler Dergis , 15(59), 1250-1262.

Datu, J. A. D. (2014). Forgiveness, gratitude, and subjective well being among Filipino adolescents. International Journal for the Advancement of Counselling. Advanced Online Publication.

Datu, J. A. D. ve Mateo, N. J. (2015). Gratitude and Life Satisfaction among Filipino Adolescents: The Mediating Role of Meaning in Life. International Journal for the Advancement of Counselling. 37, 198-206.

Demirbaş Çelik, N. (2016), Üniversite Öğrencilerinin Yaşamda Anlam ve Yaşam Amaçları Arasındaki İlişki. Mediterranean Journal of Humanities, 6/1, 133-141

Diener, E., Emmons, R. A., Larsen, R. J. ve Griffin, S. (1985). The Satisfaction With Life Scale. Journal of Personality Assessment. 49 (1), 71-75.

Emmons, R.A. (1986). Personal strivings: An approach to personality and subjective well-being. Journal of Personality and Social Psychology, 51(5), 1058-1068.

Emmons, R.A. (1999). The psychology of ultimate concerns: Motivation and spirituality in personality. New York: Guilford.

Emmons, R.A. (2004). The psychology of gratitude: an introduction. In The Psychology of Gratitude (Eds RA Emmons, ME McCullough):3-16. New York, NY, Oxford University Press.

Emmons, R. A. (2009). Gratitude. In The Encyclopedia of Positive Psychology (Eds SJ Lopez): 442-447. Hoboken, NJ, Wiley-Blackwell.

Erturan, İ., Aktepe, E., Kocaman, O., Sönmez, Y., Başak, P. Y., Ceyhan, A. M., ve Akkaya, V. B. (2014). Akneli ergenlerin yaşam kalitesi, yalnızlık ve yaşam doyumu düzeylerinin değerlendirilmesi. Türkderm Deri Hastalıklarl ve Frengi Arşivi Dergisi, 48(4), 172-176

Eryılmaz, A. (2009). Ergen öznel iyi oluş ölçeğinin geliştirilmesi, Türk Eğitim Bilimleri Dergisi, 7(4), 975-989

Eryılmaz, A. (2014). Üniversite öğrencileri için geliştirilen öznel iyi oluşu artırma programının etkililiğinin incelenmesi. Mehmet Akif Ersoy Üniversitesi Ĕgitim Fakültesi Dergisi, (31), 111-128. 
Froh, J. J., \& Bono, G. (2008). The gratitude of youth. In S. J. Lopez (Ed.), Positive psychology: Exploring the best in people, 2, 55-78. Westport: Greenwood Publishing Company.

Froh, J., Sefick, W.J. \& Emmons, R.A. (2008). Counting blessings in early adolescents: an experimental study of gratitude and subjective well-being. Journal of School Psychology, 46, 213-233.

Gilman, R., \& Ashby, J. S. (2003). A first study of perfectionism and multidimensional life satisfaction among adolescents. Journal of Early Adolescence, 23, 218-235.

Gilman, R., \& Huebner, E. S. (2003). A review of life satisfaction research with children and adolescents. School Psychology Quarterly, 18, 192-205.

Goldbeck, L., Schmitz, T.G., Besier, T., Herschbach, P., \& Henrich, G. (2007). Life satisfaction decreases during adolescence. Quality of Life Research, 16(6), 969979.

Gündoğar, D., Gül, S.S., Uskun, E., Demirci, S. ve Keçeci, D. (2007). Üniversite öğrencilerinde yaşam doyumunu yordayan etkenlerin incelenmesi. Klinik Psikiyatri Dergisi, 10, 14-27.

Huebner, E. S., Drane, J. W., \& Valois, R. F. (2000). Levels and demographic correlates of adolescent life satisfaction reports. School Psychology International, 21, 281292.

İlhan, T. ve Özbay, Y. (2010). Yaşam amaçların ve psikolojik ihtiyaç doyumunun öznel iyi oluş üzerindeki yordayıcı rolü. Türk Psikolojik Danışma ve Rehberlik Dergisi. 34 (2), 109-119.

Karasar, N. (2005). Bilimsel araştırma yöntemi. (15. Baskı). Ankara: Nobel Yayın Dağıtım.

Kardaş, F. ve Yalçın, İ. (2017). Şükran Ölçeği Geliştirme Çalışması. Sözlü Bildiri. 2. Avrasya Pozitif Psikoloji Kongresi. (12-14 Mayıs ) Üsküdar Üniversitesi: İstanbul.

Kardaş, F. ve Yalçın, İ. (2018). Şükran: Ruh Sağlığı Alanında Güncel Bir Kavram, Psikiyatride Güncel Yaklaşımlar, 10(1), 1-18

Kashdan, T.B., Mishra, A., Breen, W.E., \& Froh, J.J. (2009). Gender differences in gratitude: Examining appraisals, narratives, the willingness to express emotions, and changes in psychological needs. Journal of Personality, 77, 691-730 
Kasser, T., \& Ryan, R. M. (1996). Further examining the American dream: Differential correlates of intrinsic and extrinsic goals. Personality and Social Psychology Bulletin, 22(3), 280-287.

Kasser, T. \& Ryan, R.M. (2001). Be careful what you wish for: Optimal functioning and the relative attainment of intrinsic and extrinsic goals. In, P. Schmuck and K. Sheldon (Eds), Life goals and well-being, (116-131). Gottingen: Hogrefe.

Kermen, U., İlçin Tosun, N. ve Doğan, U . (2016). Yaşam Doyumu ve Psikolojik İyi Oluşun Yordayıc1sı Olarak Sosyal Kaygı. Eğitim Kuram ve Uygulama Araştırmaları Dergisi, 2 (1), 20-29.

Locke, E. A. (2002). Setting goals for life and happiness. In C. R. Snyder \& S. J. Lopez (Eds.), Handbook of positive psychology (pp. 299-312). New York: Oxford University Press.

Lyubomirsky, S. (2008). The how of happiness: a scientific approach to getting life you want. New York, Penguin Press.

Mosknes, U.K. \& Espnes, G.A. (2014). Self-esteem and life satisfaction in adolescents gender and age as potential moderators. Quality Of Life Research, 22(10), 29212928.

Oğuz-Duran, N., ve Tan, Ş. (2013). Minnettarlık ve yaşam amaçları yazma çalışmalarının öznel iyi oluşa etkisi. Türk Psikolojik Danışma ve Rehberlik Dergisi, 5(40), 154-166.

Proctor, C. L., Linley, P. A. \& Maltby, J. (2009). Youth Life Satisfaction: A Review of the Literature. Journal of Happiness Studies, 10, 583-630.

Roberts, R.C. (2004). The blessings of gratitude. In The Psychology of Gratitude (Eds RA Emmons, ME McCullough):58-78. New York, NY, Oxford University Press.

Seligman M.E.P., Steen, T., Park, N. \& Peterson, C. (2005). Positive psychology progress: empirical validation of interventions. American Psychologist, 60(5), 410-421.

Szczesniak,M. \& Soares, E. (2011). Are proneness to forgive, optimism and gratitude associated with life satisfaction?. Polish Psychological Bulletin, 42(1), 20-23.

Tabachnick, B.G., \& Fidell, L. S. (2001). Using multivariate statistics (fourth edition), New York, College Publishers. 
Tarhan, N., (Nisan, 2006). Gençlikte Kimlik Bunalımı-22293/ https://www.epsikiyatri.com/Genclikte-Kimlik-Bunalimi-22293 adresinden 7.01.2019 tarihinde alınmıştır.

Telef, B. B. (2013). Ergenlerin yaşam doyumlarının ve psikolojik semptomlarının incelenmesi. Yeni Symposium, 51(1), 3-12.

Wood, A. M., Joseph, S., \& Maltby, J. (2008). Gratitude uniquely predicts satisfaction with life: Incremental validity above the domains and facets of the five factor model. Personality and Individual Differences, 45, 49-54.

Yetim, U. (2003). The impacts of individualism/collectivism, selfesteem, and feeling of mastery on life satisfaction among the Turkish university students and academicians. Social Indicators Research, 61, 297-317.

Yörükoğlu, A., (2004). Gençlik çă̆l ruh sağlı̆̆l ve ruhsal sorunlar. İstanbul: Özgür Yayınları. 


\section{Summary}

\section{Statement of Problem}

Adolescence is a crucial development process, as well as many problems, are experienced in the period. According to Erikson, given the appreciation of identity or self, it would be beneficial for adolescents to face problems in a healthy way. Adolescence is an exciting, turbulent, and passionate period that affects all other areas of personal development. Young people (adolescents are trying to find themselves, prove themselves, and create the aims of their lives) in this period (Tarhan, 2019). With various activities, they try to reveal what they see as the meaning of their own lives. The aim of life enables an individual not only to lead a more meaningful life, but also to feel more satisfaction in his/her life. It is observed that individuals who set goals and make necessary efforts to achieve these goals are better in terms of subjective terms than those who do not have goals (Emmons, 1999). In addition, Gratitude is accepted as one of the essential components to achieve sustainable happiness (Lyubomirsky, 2008) and a better life. Gratitude as a widely experienced emotion expresses a tendency towards seeing life as a gift (Kardas and Yalçın, 2018). Life satisfaction is defined as a positive assessment of an individual's entire life in accordance with the criteria set out for himself or herself (Diener, Emmons, Larsen and Griffin, 1985). When the literature is examined, no study was found to investigate the status of gratitude in adolescents with life satisfaction and life goals. In order to resolve this deficiency, this study aims to investigate the relationship between life satisfaction, gratitude and life goals in adolescents at the high school level.

\section{Method}

In this study, descriptive scanning and relational scanning model was used. The sample group consists of 603 students who study in Science High Schools, Anatolia High Schools, Anatolia Religious Vocational High Schools, and Vocational and Technical Anatolian High Schools in the central districts of Van province. The questionnaires and scales were used to collect data. There are nine questions about personal information in the survey, while the Gratitude Scale consists of 25, The Life Goals Scale 31 and Life Satisfaction Scale consists of five items. All scales are Likertstyle and Cronbach alpha values were .88 for Gratitude Scale, .74 for Life Satisfaction 
Scale, and .85 for Life Goals Scale. The data were subjected to frequency (f) and percent (\%) analysis, t-test, variance analysis (ANOVA) and regression analysis.

\section{Findings}

The gender of the participants is not a variable that affecting life satisfaction and life goals but a factor affecting the level of gratitude. It was found that there was a positive relationship between gratitude levels and life satisfaction and life goals. In addition, it was found that the level of gratitude was higher in students who were educated in Science and Anatolian high schools. On the other hand, it was determined that the students who were educated in Science High Schools and Anatolia Religious Vocational High Schools had higher saturation at the point of life satisfaction. It was seen that there is a significant difference regarding the point of life goals between the students who went to Anatolia Religious Vocational High Schools and the students who went to Science High Schools. According to the income status of their families, it was determined that gratitude, life satisfaction, and life goals were significantly different. It was also found that gratitude and life goals are together explained life satisfaction at the 21\% level. Moreover, it was indicated that gratitude alone makes $19 \%$ of the satisfaction of life. Some suggestions were made to pay attention to these studies in this area.

\section{Discussion and Conclusion}

In the study, it was found that the feeling of gratitude of male students was significantly lower than that of female students. As the level of gratitude increases, the students ' success level, life goals, and life satisfaction are increased, the guidance and psychological counseling activities may include activities that increase the level of gratitude of male students.

The type of school where adolescents continue is seen to affect their gratitude, life goals, and life satisfaction. To work on issues that will make their schools attractive for adolescents will support their acceptance of their school and therefore their academic motivation and success. For example, the availability of various academic, social and cultural opportunities of schools can provide an essential opportunity for an advanced level of Education. Such features can enhance the attractiveness of the school and can be sufficient for students to feel good about themselves. The fact that the students who study in vocational and technical Anatolian high schools receive low 
scores in all areas and differ in other high schools constitutes the idea that the high school that should be addressed primarily in this field is high schools.

In the same way, intervention programs that increase the success level of students with low academic achievement can be added to gratitude education and life goals determination studies.

It is observed that the students with low economic level of their family have the low gratitude, life goals, and life satisfaction. By contacting various government agencies, providing financial support to the families of non-financial students in schools will enable adolescents to feel better. It is observed that there are significant relationships between gratitude, life satisfaction, and life goals, which are essential concepts that determine the spiritual well-being of man. Adolescents and parents based on such concepts can support the psychological development of adolescents.

In the future, researchers can work on adolescents living in different regions to find similarities or differences in their care for gratitude, life satisfaction, and life goals. In addition, programs can be prepared on the topics of gratitude, life satisfaction, and life goals suitable for different educational stages and studies can be done to determine the effects of students. 